\title{
Environmental Assessment of Infrastructure Projects of Water Sector in Baghdad, Iraq
}

\author{
Allaa M. Aenab, S. K. Singh \\ Civil and Environmental Engineering Department, Delhi Technological University (DTU), Delhi, India. \\ Email: allaaaenab@gmail.com
}

Received October $23^{\text {rd }}, 2011$; revised November $24^{\text {th }}, 2011$; accepted December $18^{\text {th }}, 2011$

\begin{abstract}
In 1970s the city of Baghdad had a good infrastructure. Education and healthcare systems were widely regarded as the best in the Middle East. Income per capita rose to over US\$3600 in the early 1980s. Since that time, successive wars and a repressive, state-dominated economic system have stifled economic growth and development and debilitated basic infrastructure and social services. At the end of the 2003 war, Baghdad's infrastructure was seriously degraded. The majority of the population had limited or inadequate access to essential basic services. Currently, there is an ongoing effort by donor countries, such as the United States (US) (through the US Agency for International Development (USAID)), Japan, the European Union (EU), etc., as well as efforts by multilateral agencies such as the United Nations Children's Fund (UNICEF), the United Nations Development Programme (UNDP), the International Committee of the Red Cross (ICRC), and Non Governmental Organizations (NGOs), to restore the sector to standards that existed prior to the latest conflict. The present study deals with the evaluation of four projects proposed to improve the deteriorating status of water and wastewater treatment plants. Three methods viz. checklist, strategic environment assessment and cost and benefit analysis are used to evaluate the efficiency of the projects.
\end{abstract}

Keywords: Water Supply; Water and Sanitation; Wastewater; Infrastructure Projects; Drinking Water; WTPs; WWTPs; EIA; Cost and Benefit

\section{Introduction}

Infrastructural projects are very crucial in the overall development of society. They cater to the basic needs of the population and promote the growth of economy. The lack of basic infrastructure services, particularly electricity, has contributed to the general lack of security in various parts of the country. Today most Iraqis have limited access to essential basic services, including electricity, water supply, sanitation, and refuse collection. Serious environmental and health risks associated with contaminated water supplies, inappropriate handling of solid waste, and disposal of sewage threaten to further burden the already stressed health system [1].

After war against America in 2003, the young Iraqi government is trying to rebuild the basic infrastructures to cater to the needs of the people. Due to rapid industrialization and population growth in some of these regions, and increasing recognition of the regional and global environmental impacts of certain development projects, the need to apply EIA in these countries effectively is apparent. Environmental assessment of the infrastructural projects is a mandatory requirement of the international sponsoring loaning agencies (UNEP, UNESCO, WHO,
JICA, World Bank etc.). The International Organization for Standardisation (ISO) Standard 14011, which covers EIA, includes principal steps such as general requirements, environmental policy, planning, implementation and operation, checking and corrective action, and management review. Many of the current assessment approaches embody the steps of prediction, scaling and significant interpretation. The scientific validity of the technology available for the prediction of impacts varies depending upon the particular environmental descriptor.

\section{Objectives and Approach}

Environmental assessment of the proposed and ongoing Infrastructural projects in water sector is the primary objective of this study. Out of the various methodologies reportedly used to assess the environmental impact assessment of the infrastructural projects, three methods viz. Cost and benefit [2], Checklist [3] and Strategic Environmental Assessment (SEA) [4], have been used for each project. Checklist approaches present types of impacts typically associated with particular categories of projects. From a master list of environmental factors and environmental impacts, impact statements preparers select 
and evaluate those impacts expected for the particular alternative under consideration. There are four basic categories of checklists viz. simple checklist, descriptive checklist, scaling checklist and scaling weighting checklist. Strategic environment assessment examines whether an intervention has achieved its intended outputs and outcomes. The challenge is to define clearly how to measure these achievements in an objective and robust manner. Finally the most contentious analysis in an EIA is the cost benefit analysis. It is a tool that decisionmakers use to choose between alternative courses of action and in deciding whether a proposed project should go ahead or not.

\section{Study Area}

The capital city of Iraq, Baghdad has been selected as the study area (Figure 1). Baghdad is located at about $33.29^{\circ} \mathrm{N}, 44.40^{\circ} \mathrm{E}$. The city lies on a vast plain bisected by the Tigris River. The Tigris splits Baghdad in half, with the Eastern half being called "Rusafa" and the Western half known as "Karkh". The study area, covering the whole Baghdad Mayoralty (BM) area, is divided into eleven administrative districts (municipalities) viz. Adhamiya, Sader 1, Sader 2, Rusafa, Nissan, Karadah, Khadamiyah, Mansour, Karkh, Rasheed and Doura [5]. Baghdad has a hot arid climate and is, in terms of maxi- mum temperatures, one of the hottest cities in the world. The city has about 7.4 million inhabitants (2005 estimate), situated in the interior of the country on the Tigris River at the point where land transportation meets river transportation, and where the distance between Tigris and the other main river of Iraq, Euphrates, is the shortest. The soil consists of about $10 \mathrm{~m}$ deep silt-clay soil strata on the surface, and thick sand/gravel strata beneath it [6]. The study region has been classified to 25 land use/land cover classes from 1973 to 2007 using ArcGIS v.9.1 software [7]. There are a wide variety of industries, producing leather goods, furniture, wood products, chemicals, electrical equipment, textiles, clothing, bricks, cement, tobacco, processed food and beverages [8].

Since 1991, the water supply and sanitation sector has experienced a steady but devastating decline. At the end of the 2003 war, Iraq's infrastructure was seriously degraded. The deficiency of basic infrastructure services has added to the general lack of security in various parts of the city. The majority of the population had limited or inadequate access to essential basic services. Those who could afford it relied on costly alternatives for electricity and water services. Contaminated water supplies, improper handling of solid waste and disposal of sewage led to environmental degradation and increased health hazards. What had escaped destruction and looting operates at minimal capacity due to years of neglect and lack

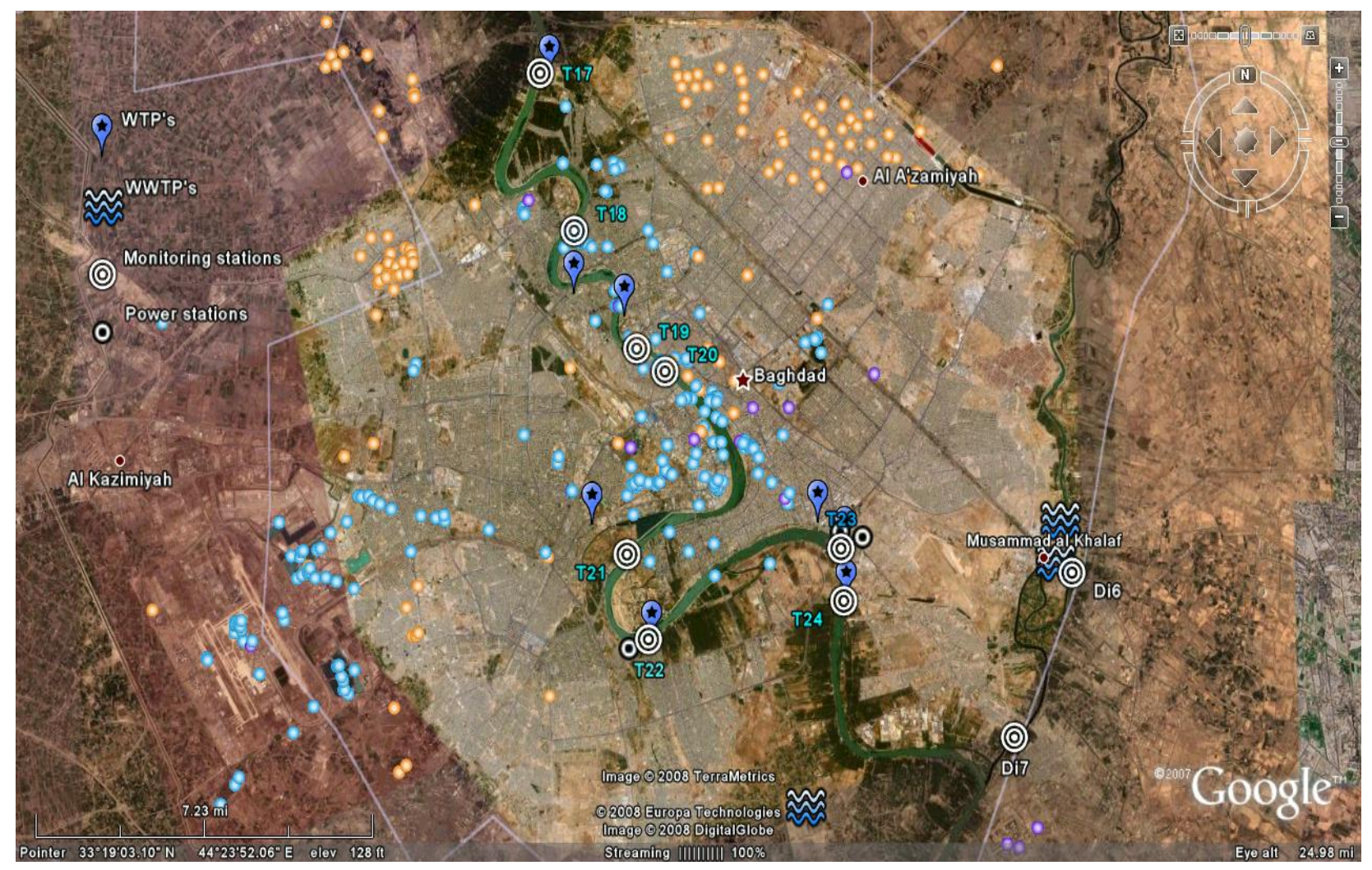

Figure 1. Baghdad map. 
of maintenance. This situation weakened urban economies and the income of the population. Without the improvement project, the current severely deteriorated public health and water environment in Baghdad will further get worse, and reducing essential services to its people. Public health conditions will continue to deteriorate in the absence of adequate sewerage services in Baghdad. Pollution of local groundwater and of the Tigris River, already serious, could rise to more dangerous levels. The disposal and waste system, and animal retention areas and pens are primitive, ineffective, and a major health risk. Furthermore, environmental standards for odour control, waste disposal, and effluent control and treatment do not exist [1].

Furthermore, the unpaved and dilapidated conditions of roads in the cities and residential quarters, the lack of proper storm water drainage, and the formation of stagnant water pools and the muddy/sandy roads' conditions are impeding the flow of human and vehicular traffic and increasing health risks. The majorities of governorates suffer from insufficient and damaged urban roads and storm water drainage, street lighting and social facilities. Improving the roads' conditions and increasing their capacity in major urban areas becomes necessary for improved access of the populations to markets and social services and for the economic well-being of the city [9].

\section{Proposed Projects}

Various infrastructural projects that are considered for the present study are described briefly below. These projects are the initiatives taken up by the government of Iraq with the support of the international funding organizations like World Bank, JICA etc. to improve the deteriorating status of water and wastewater treatment plants. They are briefly described in the following paragraphs.

\subsection{Improvement of Integrated Sewerage System in Baghdad}

In order to improve such acute deterioration of public health and environmental conditions in Baghdad, BM and the Japan International Cooperation Agency (JICA) started this project to establish an immediate improvement program for the Baghdad Sewerage System. Figure 2 represents the activity locations of project 1 The study area, covering the whole BM area, was divided into eleven administrative districts (municipalities) viz. Adhamiya, Sader 1, Sader 2, Rusafa, Nissan, Karadah, Khadamiyah, Mansour, Karkh, Rasheed and Doura. The sewer service area was divided into two sewer districts, 1) Rusafa and 2) Karkh. The study report [10] presented the results of identification and field survey on the present situation of Baghdad's sewerage system, and provided planning bases for the forthcoming Master Plan (M/P) and Feasibility Study (F/S) on the improvement of Baghdad integrated sewerage system. Also the need for the sewerage system improvement strategy plan was examined, and priority sewerage components that are to be immediately rehabilitated and/or extended were selected [11].

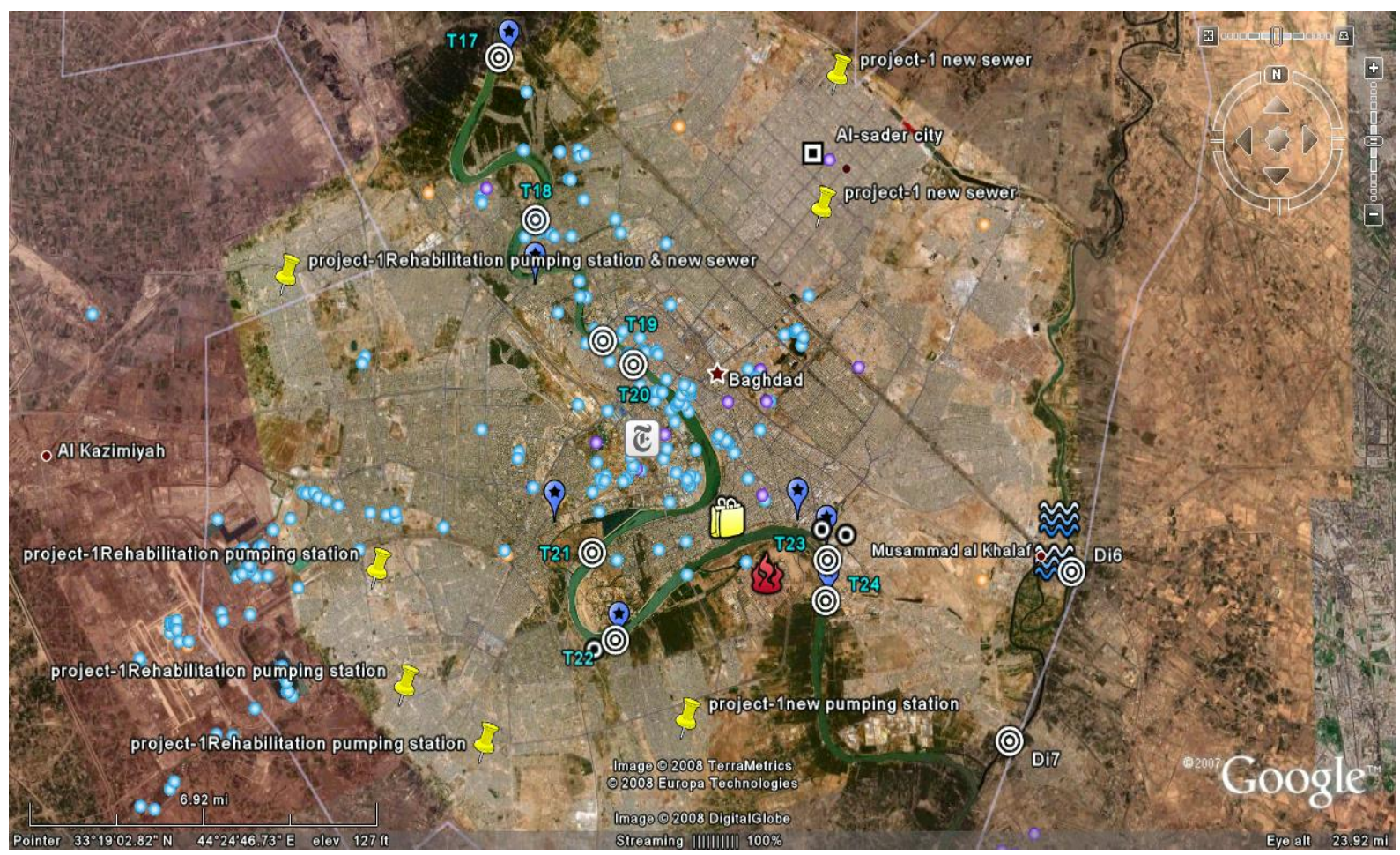

Figure 2. Location various $1^{\text {st }}$ project in Baghdad. 


\subsection{Emergency Baghdad Water Supply and Sanitation Project}

This project represented the first phase of the Emergency Infrastructure Reconstruction Program, described in the Project Information Document (PID) of April 21, 2004 [1], which intended to cover five sectors: water supply and sanitation, electricity, urban rehabilitation, transport, and telecommunications. The project addresses the urgent reconstruction needs of Baghdad including water mains, distribution pipes, sewer collectors, pumping stations, small treatment plants, and auxiliary facilities. It provides support to the MOB to better manage projects at the design, supervision, operation and maintenance stages by building the capacity of the staff working in the water supply and sanitation sector. It also includes the development of a Comprehensive City Development Plan (CCDP) to ensure that future expansion of the water supply and sanitation networks are in line with the overall urban development plan for the city. The principal objective of the project is to assist in restoring basic water supply and sanitation services for the capital city of Baghdad through 1) the reconstruction and rehabilitation of existing priority networks and treatment facilities and 2) providing capacity building support through training and technical assistance.

\subsection{Emergency Water Supply, Sanitation and Urban Reconstruction Project}

The project represents the part of the Emergency Infrastructure Reconstruction Program, described in the Project Information Document (PID) of April 21, 2004, which intended to cover five sectors: water supply and sanitation, electricity, urban rehabilitation, transport, and telecommunications [9]. The project addresses the urgent sectoral needs of urban communities outside Baghdad including rehabilitation of water and sewer networks, pumping stations, small treatment plants, community roads and other urban facilities. It provides support to the MMWP to better manage projects at the design, supervision, operation and maintenance stages by building the capacity of its staff.

The principal objective of the project is to restore some basic water supply, sanitation and urban services for urban areas outside Baghdad City through 1) the reconstruction and rehabilitation of existing facilities, and 2) providing capacity building support through training and technical assistance. This project also aims to improve the existing environmental and health conditions by renewing the old water networks and sanitation services. It will also contribute to the reduction of waterborne diseases through the reduction of water supply by tankers and the provision of potable water and sanitation networks. This would also help improve the economic con- ditions of the population by reducing the amounts of water obtained from tankers, which is generally more expensive.

\subsection{Baghdad Infrastructure Reconstruction}

The principal objective of the project is to restore essential infrastructure and services by addressing the urgent reconstruction needs highlighted in the Needs Assessment. The project will also create badly needed employment; and it will help build Iraq's capacity to manage large-scale reconstruction. The component of this project includes rehabilitation of chlorine and chemical process in all water treatment plants, rehabilitation of pumping stations in all water treatment plants, constructing of new networks for newly planned cities and sub-cities, technical assistance and capacity building [12].

\section{Results of Environmental Assessment}

The details of evaluation for the first project are given below. The results of checklist are presented in Table 1 (water supply checklist) and Table 2 (sewage treatment checklist). The results for cost and benefit analysis are shown in Table 3. The same procedure of analysis has been adopted for the other three projects and overview is presented in the end. In the checklist for water supply and sewerage certain numerical values have been assigned which measure the impact of a particular condition in the checklist. These numerical values range from 0 to 5 where 0 means no impact and 5 means maximum impact. These values were assigned on the basis of visual interpretation of the project site and information provided by the Ministry of Environment.

The first project (Improvement of integrated sewerage system in Baghdad) satisfied all the conditions included in the checklist and the Strategic Environmental Assessment (SEA) method. From the cost and benefit method, the cost involved in the project was evaluated to be 2714 $\times 10^{6}$ US $\$$ the benefit $6185 \times 10^{6}$ US\$. This gives a B.C Ratio of 2.28, which is greater than 1 , indicating that the benefit obtained is more than the cost involved.

A brief discussion on the results obtained for the other projects is presented below:

In case of the second project there were certain conditions mentioned in the checklist for water supply that were not fulfilled. The intake wells were not adequately protected, inadequate buffer zone around pumping stations and treatment plants to reduce noise. This project also lead to relocation of people and an increase in road traffic due to interference of construction activities. There was an excessive abstraction of water affecting downstream water users. In the case of the checklist for sewage and sanitation many conditions were violated. There was interference with other utilities and blockage of access 
Table 1. Checklist for water supply for Project 1.

Rapid Environmental Assessment (REA) Checklists WATER SUPPLY

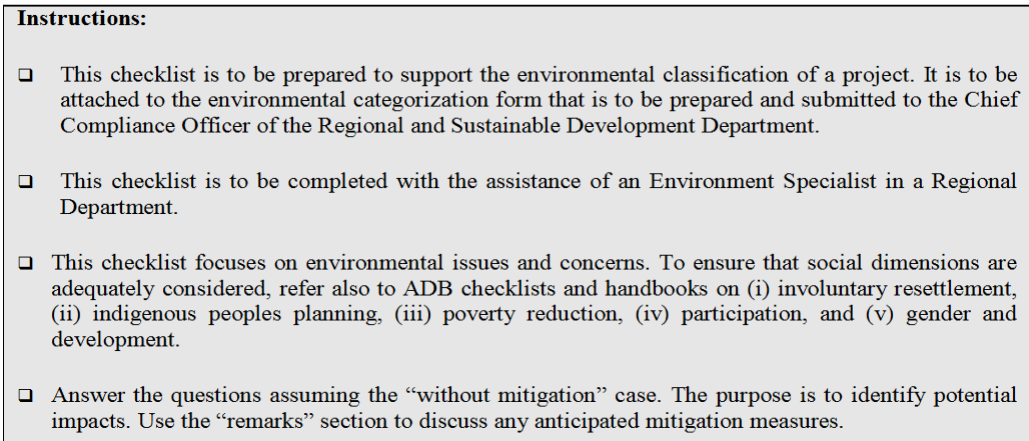

a This checklist is to be prepared to support the environmental classification of a project. It is to be attached to the environmental categorization form that is to be prepared and submitted to the Chief Compliance Officer of the Regional and Sustainable Development Department.

a This checklist is to be completed with the assistance of an Environment Specialist in a Regional Department.

- This checklist focuses on environmental issues and concerns. To ensure that social dimensions are adequately considered, refer also to ADB checklists and handbooks on (i) involuntary resettlement, (ii) indigenous peoples planning, (iii) poverty reduction, (iv) participation, and (v) gender and development.

a Answer the questions assuming the "without mitigation" case. The purpose is to identify potential impacts. Use the "remarks" section to discuss any anticipated mitigation measures.

\section{Country/Project Title: Improvement of integrated sewerage system}

Sector Division:

\section{Baghdad, IRAQ}

\begin{tabular}{|c|c|c|c|}
\hline SCREENING QUESTIONS & Yes & No & Range (5-0) \\
\hline $\begin{array}{l}\text { A. Project Sitting } \\
\text { Is the project area... }\end{array}$ & $\square$ & $\square$ & \\
\hline - Densely populated? & $\square$ & $\square$ & \\
\hline - Heavy with development activities? & $\square$ & $\square$ & \\
\hline \multicolumn{4}{|l|}{$\begin{array}{l}\text { - Adjacent to or within any environmentally sensitive } \\
\text { areas? }\end{array}$} \\
\hline - Cultural heritage site & $\square$ & & \\
\hline - Protected Area & $\square$ & $\square$ & \\
\hline - Wetland & $\square$ & $\square$ & \\
\hline - Mangrove & $\square$ & $\square$ & \\
\hline - Estuarine & $\square$ & $\square$ & \\
\hline - Buffer zone of protected area & $\square$ & $\square$ & \\
\hline - Special area for protecting biodiversity & $\square$ & $\square$ & \\
\hline - Bay & $\square$ & $\square$ & \\
\hline \multicolumn{4}{|l|}{$\begin{array}{l}\text { B. POTENTIAL ENVIRONMENTAL IMPACTS } \\
\text { Will the Project cause... }\end{array}$} \\
\hline $\begin{array}{l}\text { - pollution of raw water supply from upstream wastewater } \\
\text { discharge from communities, industries, agriculture, and } \\
\text { soil erosion runoff? }\end{array}$ & $\square$ & $\square$ & $\mathbf{0}$ \\
\hline $\begin{array}{l}\text { - impairment of historical/cultural monuments/areas and } \\
\text { loss/damage to these sites? }\end{array}$ & $\square$ & $\square$ & $\mathbf{0}$ \\
\hline $\begin{array}{l}\text { - hazard of land subsidence caused by excessive ground } \\
\text { water pumping? }\end{array}$ & $\square$ & $\square$ & $\mathbf{0}$ \\
\hline $\begin{array}{l}\text { - social conflicts arising from displacement of } \\
\text { communities? }\end{array}$ & $\square$ & $\square$ & $\mathbf{0}$ \\
\hline $\begin{array}{l}\text { - conflicts in abstraction of raw water for water supply with } \\
\text { other beneficial water uses for surface and ground waters? }\end{array}$ & $\square$ & $\square$ & $\mathbf{0}$ \\
\hline $\begin{array}{l}\text { - unsatisfactory raw water supply (e.g. excessive } \\
\text { pathogens or mineral constituents)? }\end{array}$ & $\square$ & $\square$ & $\mathbf{0}$ \\
\hline - delivery of unsafe water to distribution system? & $\square$ & 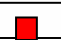 & $\mathbf{0}$ \\
\hline $\begin{array}{l}\text { - inadequate protection of intake works or wells, leading } \\
\text { to pollution of water supply? }\end{array}$ & $\square$ & $\square$ & $\mathbf{0}$ \\
\hline $\begin{array}{l}\text { - over pumping of ground water, leading to salinization } \\
\text { and ground subsidence? }\end{array}$ & $\square$ & $\square$ & $\mathbf{0}$ \\
\hline - excessive algal growth in storage reservoir? & $\square$ & $\square$ & $\mathbf{0}$ \\
\hline
\end{tabular}




\begin{tabular}{|c|c|c|c|}
\hline SCREENING QUESTIONS & Yes & No & Range (5-0) \\
\hline $\begin{array}{l}\text { - increase in production of sewage beyond capabilities of } \\
\text { community facilities? }\end{array}$ & & $\square$ & 3 \\
\hline $\begin{array}{l}\text { - inadequate disposal of sludge from water treatment } \\
\text { plants? }\end{array}$ & $\square$ & & $\mathbf{0}$ \\
\hline $\begin{array}{l}\text { - inadequate buffer zone around pumping and treatment } \\
\text { plants to alleviate noise and other possible nuisances and } \\
\text { protect facilities? }\end{array}$ & $\square$ & & $\mathbf{0}$ \\
\hline $\begin{array}{l}\text { - impairments associated with transmission lines and } \\
\text { access roads? }\end{array}$ & $\square$ & & $\mathbf{0}$ \\
\hline $\begin{array}{l}\text { - health hazards arising from inadequate design of facilities } \\
\text { for receiving, storing, and handling of chlorine and other } \\
\text { hazardous chemicals. }\end{array}$ & $\square$ & & $\mathbf{0}$ \\
\hline $\begin{array}{l}\text { - health and safety hazards to workers from the } \\
\text { management of chlorine used for disinfection and other } \\
\text { contaminants? }\end{array}$ & $\square$ & & $\mathbf{0}$ \\
\hline - dislocation or involuntary resettlement of people & $\overline{5}$ & & 3 \\
\hline $\begin{array}{l}\text { - social conflicts between construction workers from other } \\
\text { areas and community workers? }\end{array}$ & $\square$ & & $\mathbf{0}$ \\
\hline - noise and dust from construction activities? & $\square$ & & 1 \\
\hline $\begin{array}{l}\text { - increased road traffic due to interference of construction } \\
\text { activities? }\end{array}$ & $\square$ & $\square$ & 5 \\
\hline $\begin{array}{l}\text { - continuing soil erosion/silt runoff from construction } \\
\text { operations? }\end{array}$ & $\square$ & & $\mathbf{0}$ \\
\hline $\begin{array}{l}\text { - delivery of unsafe water due to poor O\&M treatment } \\
\text { processes (especially mud accumulations in filters) and } \\
\text { inadequate chlorination due to lack of adequate } \\
\text { monitoring of chlorine residuals in distribution systems? }\end{array}$ & $\square$ & & $\mathbf{0}$ \\
\hline $\begin{array}{l}\text { - delivery of water to distribution system, which is } \\
\text { corrosive due to inadequate attention to feeding of } \\
\text { corrective chemicals? }\end{array}$ & $\square$ & & $\mathbf{0}$ \\
\hline - accidental leakage of chlorine gas? & $\square$ & & $\mathbf{0}$ \\
\hline $\begin{array}{l}\text { - excessive abstraction of water affecting downstream } \\
\text { water users? }\end{array}$ & $\square$ & & $\mathbf{0}$ \\
\hline - competing uses of water? & $\square$ & & $\mathbf{0}$ \\
\hline - increased sewage flow due to increased water supply. & $\square$ & $\square$ & 1 \\
\hline $\begin{array}{l}\text { - increased volume of sullage (wastewater from cooking } \\
\text { and washing) and sludge from wastewater treatment plant }\end{array}$ & $\square$ & & $\mathbf{0}$ \\
\hline
\end{tabular}

Table 2. Checklist for sewage treatment for Project 1.

\section{Rapid Environmental Assessment (REA) Checklist}

\section{Instructions:}

a This checklist is to be prepared to support the environmental classification of a project. It is to be attached to the environmental categorization form that is to be prepared and submitted to the Chief Compliance Officer of the Regional and Sustainable Development Department.

a This checklist is to be completed with the assistance of an Environment Specialist in a Regional Department.

a This checklist focuses on environmental issues and concerns. To ensure that social dimensions are adequately considered, refer also to $\mathrm{ADB}$ checklists and handbooks on (i) involuntary resettlement, (ii) indigenous peoples planning, (iii) poverty reduction, (iv) participation, and (v) gender and development.

a Answer the questions assuming the "without mitigation" case. The purpose is to identify potential impacts. Use the "remarks" section to discuss any anticipated mitigation measures.

\begin{tabular}{lll} 
Country/Project Title: & \multicolumn{1}{|c|}{ Improvement of integrated sewerage system } \\
\hline
\end{tabular}

Sector Division:

Baghdad, IRAQ 


\begin{tabular}{|c|c|c|c|}
\hline SCREENING QUESTIONS & Yes & No & Range (5-0) \\
\hline \multicolumn{4}{|l|}{$\begin{array}{l}\text { B. Project Siting } \\
\text { Is the project area... }\end{array}$} \\
\hline - Densely populated? & $\square$ & $\square$ & \\
\hline - Heavy with development activities? & $\square$ & $\square$ & \\
\hline $\begin{array}{l}\text { - Adjacent to or within any environmentally } \\
\text { sensitive areas? }\end{array}$ & $\square$ & $\square$ & \\
\hline - Cultural heritage site & $\square$ & $\square$ & \\
\hline - Protected Area & $\square$ & $\square$ & \\
\hline - Wetland & $\square$ & L & \\
\hline - $\quad$ Mangrove & $\square$ & [ & \\
\hline - Estuarine & $\square$ & L & \\
\hline - Buffer zone of protected area & $\square$ & ए & \\
\hline - Special area for protecting biodiversity & $\square$ & L & \\
\hline - Bay & $\square$ & ⿷ & \\
\hline \multicolumn{4}{|l|}{$\begin{array}{l}\text { A. Potential Environmental Impacts } \\
\text { Will the Project cause... }\end{array}$} \\
\hline $\begin{array}{l}\text { - impairment of historical/cultural } \\
\text { monuments/areas and loss/damage to these } \\
\text { sites? }\end{array}$ & $\square$ & & $\mathbf{0}$ \\
\hline $\begin{array}{l}\text { - interference with other utilities and blocking } \\
\text { of access to buildings; nuisance to } \\
\text { neighboring areas due to noise, smell, and } \\
\text { influx of insects, rodents, etc.? }\end{array}$ & $\square$ & L & $\mathbf{0}$ \\
\hline $\begin{array}{l}\text { - dislocation or involuntary resettlement of } \\
\text { people. }\end{array}$ & $\square$ & $\square$ & 3 \\
\hline $\begin{array}{l}\text { - impairment of downstream water quality due } \\
\text { to inadequate sewage treatment or release of } \\
\text { untreated sewage? }\end{array}$ & $\square$ & [ & $\mathbf{0}$ \\
\hline $\begin{array}{l}\text { - overflows and flooding of neighboring } \\
\text { properties with raw sewage? }\end{array}$ & $\square$ & [ & $\mathbf{0}$ \\
\hline $\begin{array}{l}\text { - environmental pollution due to inadequate } \\
\text { sludge disposal or industrial waste discharges } \\
\text { illegally disposed in sewers? }\end{array}$ & $\square$ & 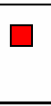 & $\mathbf{0}$ \\
\hline $\begin{array}{l}\text { noise and vibration due to blasting and other } \\
\text { civil works? }\end{array}$ & $\square$ & [ & $\mathbf{0}$ \\
\hline $\begin{array}{l}\text { - discharge of hazardous materials into sewers, } \\
\text { resulting in damage to sewer system and } \\
\text { danger to workers? }\end{array}$ & $\square$ & $\Gamma$ & 1 \\
\hline $\begin{array}{l}\text { - inadequate buffer zone around pumping and } \\
\text { treatment plants to alleviate noise and other } \\
\text { possible nuisances, and protect facilities? }\end{array}$ & $\square$ & C & 2 \\
\hline $\begin{array}{l}\text { - social conflicts between construction workers } \\
\text { from other areas and community workers? }\end{array}$ & $\square$ & & $\mathbf{0}$ \\
\hline $\begin{array}{l}\text { road blocking and temporary flooding due to } \\
\text { land excavation during the rainy season? }\end{array}$ & $\square$ & & $\mathbf{0}$ \\
\hline $\begin{array}{l}\text { - noise and dust from construction activities? } \\
\text { - traffic disturbances due to construction } \\
\text { material transport and wastes? }\end{array}$ & $\square$ & & $\mathbf{1}$ \\
\hline - temporary silt runoff due to construction? & $\square$ & $\square$ & $\mathbf{0}$ \\
\hline $\begin{array}{l}\text { - hazards to public health due to overflow } \\
\text { flooding, and groundwater pollution due to } \\
\text { failure of sewerage system? }\end{array}$ & $\square$ & $\square$ & $\mathbf{0}$ \\
\hline $\begin{array}{l}\text { - deterioration of water quality due to } \\
\text { inadequate sludge disposal or direct discharge } \\
\text { of untreated sewage water? }\end{array}$ & $\square$ & $\square$ & $\mathbf{0}$ \\
\hline $\begin{array}{l}\text { - contamination of surface and ground waters } \\
\text { due to sludge disposal on land? }\end{array}$ & $\square$ & $\square$ & $\mathbf{0}$ \\
\hline $\begin{array}{l}\text { - health and safety hazards to workers from } \\
\text { toxic gases and hazardous materials which } \\
\text { maybe contained in sewage flow and } \\
\text { exposure to pathogens in sewage and sludge? }\end{array}$ & $\square$ & $\square$ & $\mathbf{0}$ \\
\hline
\end{tabular}


Environmental Assessment of Infrastructure Projects of Water Sector in Baghdad, Iraq

Table 3. Cost and benefit analysis for Project 1.

\begin{tabular}{|c|c|c|c|c|c|c|}
\hline & Cost & Benefit & Net benefit & Pwb & Pwc & Pwnb \\
\hline & $\times 10^{6}$ & $\times 10^{6}$ & $\times 10^{6}$ & $\times 10^{6}$ & $\times 10^{6}$ & $\times 10^{6}$ \\
\hline 2005 & 0.00 & 0.00 & 0.00 & 0.00 & 0.00 & 0.00 \\
\hline 2006 & 86.00 & 0.00 & -86.00 & -32.59 & 32.59 & -65.18 \\
\hline 2007 & 131.00 & 0.00 & -131.00 & -50.64 & 50.64 & -101.27 \\
\hline 2008 & 121.00 & 0.00 & -121.00 & -47.71 & 47.71 & -95.41 \\
\hline 2009 & 32.00 & 0.00 & -32.00 & -12.87 & 12.87 & -25.74 \\
\hline 2010 & 131.00 & 0.00 & -131.00 & -53.74 & 53.74 & -107.47 \\
\hline 2011 & 131.00 & 0.00 & -131.00 & -54.81 & 54.81 & -109.62 \\
\hline 2012 & 129.00 & 0.00 & -129.00 & -55.05 & 55.05 & -110.11 \\
\hline 2013 & 32.00 & 0.00 & -32.00 & -13.93 & 13.93 & -27.86 \\
\hline 2014 & 32.00 & 0.00 & -32.00 & -14.21 & 14.21 & -28.42 \\
\hline 2015 & 85.00 & 0.00 & -85.00 & -38.50 & 38.50 & -76.99 \\
\hline 2016 & 85.00 & 0.00 & -85.00 & -39.27 & 39.27 & -78.53 \\
\hline 2017 & 80.00 & 0.00 & -80.00 & -37.69 & 37.69 & -75.39 \\
\hline 2018 & 80.00 & 0.00 & -80.00 & -38.45 & 38.45 & -76.90 \\
\hline 2019 & 58.00 & 232.00 & 174.00 & 85.30 & 28.43 & 56.87 \\
\hline 2020 & 59.16 & 236.64 & 177.48 & 88.74 & 29.58 & 59.16 \\
\hline 2021 & 60.34 & 241.37 & 181.03 & 92.33 & 30.78 & 61.55 \\
\hline 2022 & 61.55 & 246.20 & 184.65 & 96.06 & 32.02 & 64.04 \\
\hline 2023 & 62.78 & 251.12 & 188.34 & 99.94 & 33.31 & 66.63 \\
\hline 2024 & 64.04 & 256.15 & 192.11 & 103.98 & 34.66 & 69.32 \\
\hline 2025 & 65.32 & 261.27 & 195.95 & 108.18 & 36.06 & 72.12 \\
\hline 2026 & 66.62 & 266.50 & 199.87 & 112.55 & 37.52 & 75.03 \\
\hline 2027 & 67.96 & 271.82 & 203.87 & 117.10 & 39.03 & 78.06 \\
\hline 2028 & 69.32 & 277.26 & 207.95 & 121.83 & 40.61 & 81.22 \\
\hline 2029 & 70.70 & 282.81 & 212.11 & 126.75 & 42.25 & 84.50 \\
\hline 2030 & 72.12 & 288.46 & 216.35 & 131.87 & 43.96 & 87.91 \\
\hline 2031 & 73.56 & 294.23 & 220.67 & 137.20 & 45.73 & 91.47 \\
\hline 2032 & 75.03 & 300.12 & 225.09 & 142.74 & 47.58 & 95.16 \\
\hline 2033 & 76.53 & 306.12 & 229.59 & 148.51 & 49.50 & 99.00 \\
\hline 2034 & 78.06 & 312.24 & 234.18 & 154.51 & 51.50 & 103.00 \\
\hline 2035 & 79.62 & 318.49 & 238.86 & 160.75 & 53.58 & 107.17 \\
\hline 2036 & 81.21 & 324.86 & 243.64 & 167.24 & 55.75 & 111.50 \\
\hline 2037 & 82.84 & 331.35 & 248.51 & 174.00 & 58.00 & 116.00 \\
\hline 2038 & 84.50 & 337.98 & 253.49 & 181.03 & 60.34 & 120.69 \\
\hline 2039 & 86.18 & 344.74 & 258.55 & 188.34 & 62.78 & 125.56 \\
\hline 2040 & 87.91 & 351.63 & 263.73 & 195.95 & 65.32 & 130.63 \\
\hline 2041 & 89.67 & 358.67 & 269.00 & 203.87 & 67.96 & 135.91 \\
\hline 2042 & 91.46 & 365.84 & 274.38 & 212.11 & 70.70 & 141.40 \\
\hline 2043 & 93.29 & 373.16 & 279.87 & 220.67 & 73.56 & 147.12 \\
\hline 2044 & 95.16 & 380.62 & 285.47 & 229.59 & 76.53 & 153.06 \\
\hline 2045 & 97.06 & 388.23 & 291.17 & 238.86 & 79.62 & 159.24 \\
\hline 2046 & 99.00 & 396.00 & 297.00 & 248.51 & 82.84 & 165.68 \\
\hline 2047 & 100.98 & 403.92 & 302.94 & 258.55 & 86.18 & 172.37 \\
\hline 2048 & 103.00 & 412.00 & 309.00 & 269.00 & 89.67 & 179.33 \\
\hline 2049 & 105.06 & 420.24 & 315.18 & 279.87 & 93.29 & 186.58 \\
\hline 2050 & 107.16 & 428.64 & 321.48 & 291.17 & 97.06 & 194.12 \\
\hline 2051 & 109.30 & 437.21 & 327.91 & 302.94 & 100.98 & 201.96 \\
\hline 2052 & 111.49 & 445.96 & 334.47 & 315.18 & 105.06 & 210.12 \\
\hline 2053 & 113.72 & 454.88 & 341.16 & 327.91 & 109.30 & 218.61 \\
\hline 2054 & 115.99 & 463.97 & 347.98 & 341.16 & 113.72 & 227.44 \\
\hline Total & & & & 6185 & 2714 & 3471 \\
\hline
\end{tabular}

B.C Ratio $=2.28$. 
to buildings, nuisance to neighboring areas due to rodents, insects and noise. There was dislocation or involuntary resettlement of people, inadequate buffer zone around the pumping stations and social conflicts between construction workers from other areas. Apart from this there was a lot of noise and dust from construction activities, traffic disturbances due to construction material temporary silt runoff due to construction. The SEA method showed that the project is unable to avoid conflicts between the water users. There was inadequate protection of intake wells and no buffer facilities have been provided to alleviate noise. The pumping stations for waste were not given enough buffer facilities and due to improper waste disposal techniques the downstream water quality was found to be bad.

Finally the total cost involved in the project is $267 \times$ $10^{6}$ US\$ and the benefit attained was $367 \times 10^{6}$ US\$. The B.C Ratio thus came out to be 1.33 . Since the B.C Ratio is greater than 1 , it indicates that the benefit attained is greater than the cost involved.

For the third project the water supply checklist indicated that there was inadequate buffer zone around pumping and treatment plants to alleviate noise and other possible nuisances and protect facilities. The project caused dislocation or involuntary resettlement of people. There was a lot of noise and dust from construction activities. There was increased volume of sullage and sludge from the wastewater treatment plant. The sewage treatment plants were flooded with overflowing sewage, blocking access to building and some were breeding grounds for mosquetoes and rodents. In some places there was discharge of hazardous materials into sewers resulting in blockage. Due to lack of funds and frequent wars, proper care was not taken towards groundwater pollution due to untreated sewage. The SEA method showed that in case of water supply the project satisfies all the conditions except for one condition, which said that no buffer facility was provided around the project to alleviate noise and other nuisances. This resulted in a lot of noise pollution in the surrounding areas. In case of sewage and sanitation checklist, the sewage pumping stations were located within the city and not well kept. They were not well buffered and in unhygienic conditions. In some cases the intake of the sewage treatment plants was more than its capacity, which lead to unhygienic conditions in the surrounding areas. Further, considering the cost and benefit method it was found that the cost involved in this project was $37 \times 10^{6}$ US\$ and the benefit obtained was $62 \times 10^{6}$ US\$. Thus the B.C Ratio came out to be 1.67. Since the B.C Ratio is greater than 1 , it showed that the benefit is greater than the cost, which further indicated that the project is good. The total cost involved was found to be $267 \times 10^{6}$ US\$ and the benefit attained, $367 \times 10^{6}$ US\$. The B.C. Ratio came out to be 1.33. In this case also the B.C Ratio is greater than 1 , which indicated that the benefit is greater than the cost.

In case of the $4^{\text {th }}$ project, the checklist for water supply showed that there is an inadequate protection of intake wells or works, leading to the pollution of water supply, increase in production of sewage beyond capabilities of community facilities, inadequate buffer zone around pumping stations and treatment plants to lower down noise, insufficient health and safety hazards to workers from the management of chlorine used for disinfection and other contaminants. In the checklist for sewage treatment most of the conditions were not satisfied. The conditions that were satisfied were adequate protection of historical places, adequate buffer zone protection to the pumping stations, settling social conflicts among the water users, protection from noise and dust and avoiding traffic disturbances. From the SEA method it was seen that in case of water supply, sometimes the treatment plant capacity was less than the intake due to which large qualities of wastewater and sewage was thrown untreated. The pumping stations were located within the cities and were not well maintained giving rise to noise pollution and unhygienic conditions. Further, from the cost and benefit method, it was found that the total cost involved is $351 \times 10^{6}$ US\$ and benefit, $395 \times 10^{6}$ US\$. Thus the B.C Ratio was 1.12 . This Ratio is again greater than 1 , which shows the benefit is greater than the cost.

\section{Conclusions}

After evaluation one can say that the first project is the best project, the next best project is the third project followed by the second project and finally the least good project is the fourth project.

\section{REFERENCES}

[1] World Bank, "Emergency Baghdad Water Supply and Sanitation Project," World Bank Iraq Trust Fund, Washington DC, 2004, pp. 5-38.

[2] R. J. Kopp, A. J. Krupnick and M. Toman, “Cost-Benefit Analysis and Regulatory Reform: An Assessment of the Science and the Art," Discussion Paper, Resources for the Future, Washington DC, 1997, pp. 79-86.

[3] ADB, “Environmental Assessment Guidelines,” Asian Development Bank, Mandaluyong City, 2003, pp 96-145.

[4] DAC, “Applying Strategic Environmental Assessment," Development Assistance Committee DAC Guidelines and Reference Series,” OECD Organization for Economic CoOperation and Development, Washington, 2006, pp. 1764.

[5] S. A. H. Saleh, A. F. Al-Bayati Sataa and A. W. Izzat Maha, "Evaluation and Forecasting of Baghdad City Public Services by GIS Techniques,” University of Technology Baghdad, Baghdad, 2007, pp. 5-12.

[6] Md. J. B. Alam, M. S. Rahman and M. H. Hossain, “As- 
sessment of Population Exposure Risk and Risk Zones due to Surface Water Quality by GIS-A Case Study on Sylhet," ARPN Journal of Engineering and Applied Sciences, 2006, pp. 1-3.

[7] S. A. H. Saleh, "Remote Sensing Technique for Land Use and Surface Temperature Analysis for Baghdad, Iraq," University of Al-Nahrain, Baghdad, 2003, pp. 9-10.

[8] Central Intelligence Agency (CIA), "The Online Factbook Is Updated Periodically throughout the Year," McLean, 2008, pp. 1-13.

[9] World Bank, "Emergency water Supply, Sanitation and
Urban Reconstruction Project," World Bank Iraq Trust Fund, Washington DC, 2004, pp. 8-94.

[10] UNEP Report, "Experience Funds for Project Provided to UN Trust Fund by Japanese Government, to Be Implemented by UNEP," United Nations Environment Programme, Media, 2004, pp. 22-36.

[11] JICA, Japan International Cooperation Agency Guidelines for Environmental and Social Considerations, Tokyo, 2004, pp. 11-20.

[12] World Bank Report, "Emergency Infrastructure Reconstruction Project,” Washington DC, 2004, pp. 1-8. 